\title{
Multi-criteria potential groundwater contamination and human activities: Araras watershed, Brazil
}

\section{Análise Multicritério para avaliação do potencial de contaminação de aquíferos por atividades antrópicas: bacia do rio das Araras, Brasil}

Fabíola Geovanna Piga ${ }^{1}$, Nícolas Guerra Rodrigues Tão $^{1}$, Mayara Herrmann Ruggiero ${ }^{1}$, Darlan de Souza Marquezola ${ }^{1}$, Welliton Leandro de Oliveira Boina ${ }^{1}$, Carlos Wilmer Costa ${ }^{1}$, José Augusto de Lollo ${ }^{2}$, Reinaldo Lorandi ${ }^{1}$,

Edson Augusto Melanda ${ }^{1}$ and Luiz Eduardo Moschini ${ }^{1}$

${ }^{1}$ Universidade Federal de São Carlos, São Carlos, SP, Brazil

${ }^{2}$ Universidade Estadual Paulista "Júlio de Mesquita Filho", Ilha Solteira, SP, Brazil

E-mails: fabipiga@gmail.com (FGP), nicguerra@gmail.com (NGRT), mayara.hruggiero@gmail.com (MHR),dz.marquezola@gmail.com (DSM), wellynghton@gmail.com (WLOB), carloswilmercosta@gmail.com (CWC), ja_lollo@yahoo.com (JAL), lorandir@gmail.com (RL), melanda@ufscar.br(EAM), lemoschini@ufscar.br (LEM)

Received: April 6, 2017 - Revised: August 17, 2017 - Accepted: September 20, 2017

\begin{abstract}
Assessment of groundwater contamination potential using geological, hydrological and hydrogeological attributes, is an efficient mechanism of sub-surface water resources protection and conservation. However, usually this method does not take into consideration the potentially polluting human activities, either in punctual or diffuse sources, or because the relative importance of the attributes are not considered. The paper proposes a multi-criteria approach as a way of solving this gap, reducing subjectivity and considering land use/cover due human actions influence in the process. The study was developed in Araras river watershed (Paraná Basin, Brazil) using rock, groundwater, relief, soils, and land use/land cover classification, employing multi-criteria analysis and data of contamination sources. The potential contamination classification showed the predominance ( $54 \%$ of the area) of very high and high potential, especially due to geological environment conditions (exploitation areas and groundwater recharge of the Itararé Aquifer - clastic sedimentary and free flow). The contaminant sources analyzed are located mainly in higher potential contamination areas.
\end{abstract}

Keywords: Groundwater; Water quality; Water contamination; Multi-criteria analysis.

\section{RESUMO}

A avaliação do potencial de contaminação da água subterrânea a partir dos atributos geológicos, hidrológicos e hidrogeológicos, é reconhecida como um mecanismo eficiente de proteção e conservação dos recursos hídricos de subsuperfície. No entanto, tal método por vezes apresenta como deficiências a desconsideração das atividades humanas que são potencialmente contaminantes, seja na forma de fontes pontuais ou difusas, ou por não considerar a importância relativa dos atributos na análise. Visando contribuir para a solução dessa lacuna, o presente trabalho se valeu de análise multicritério como forma de reduzir a subjetividade dessa análise e de informações de uso e cobertura do solo e de fontes de contaminação para tratar os efeitos da ação humana no processo. O trabalho foi desenvolvido na Bacia Hidrográfica do rio das Araras (Bacia do Paraná, Brasil) a partir do tratamento dos dados de substrato rochoso, hidrografia, relevo, solos, classificação de uso e cobertura do solo usando análise multicritério e dados de fontes de contaminação. A classificação do potencial de contaminação mostrou a predominância ( $54 \%$ da área) de áreas classificadas como potencial muito alto e alto, especialmente em função do ambiente geológico (áreas de explotação e recarga do Aquífero Itararé, sedimentar clástico e livre). As fontes contaminantes analisadas se localizam principalmente nessas áreas com maiores potenciais de contaminação.

Palavras-chave: Aquífero; Qualidade hídrica; Contaminação hídrica; Análise multicritério. 


\section{INTRODUCTION}

The expansion of human activities and population growth increases the demand for water resources. Groundwater resources have its usage increasing due to supply human communities. It is estimated that $20 \%$ of the world's aquifers are being overexploited (WWAP, 2015). In addition to increasing the consumption of groundwater, population growth tends to increase groundwater pollution. The expansion of human activities modifies groundwater quality and availability (HOWARD, 2002; MENEZES et al., 2014; COSTA et al., 2015a; MENG et al., 2015).

The concept of groundwater vulnerability assumes that the natural environment may provide some degree of protection to groundwater against contaminants (ODLING et al., 2015). Aquifer vulnerability can vary depending on the geological characteristics (rock composition, texture and structure); hydrogeological processes (recharge, water table depth); existing contaminants and human activities related to land use / land cover (GREEN et al., 2011; SRIVASTAVA et al., 2013; LI; MERCHANT, 2013). In free flow aquifers, this potential is higher due to the rapid recharge of the geological unit (IRITANI; EZAKI, 2009). Vulnerability indicates the potential for contamination of groundwater resources according to natural and manmade activities (AL HALLAQ; ELAISH, 2012; BETANCUR et al., 2013; DUCCI; SELLERINO, 2013; EDET, 2014).

The assessment of groundwater vulnerability is a very used tool throughout the world for management measures adoption (FUEST et al., 1998; JACKSON; DWARAKANATH, 1999; AL-ZABET, 2002; FOSTER; HIRATA; ANDREO, 2013; ODLING et al., 2015). Mapping vulnerability provides the spatial basis for an effective and sustainable management of groundwater resources as it allows identifying how natural aquifer properties and human made pressures can affect groundwater resources quality (FOSTER; HIRATA; ANDREO, 2013; SRIVASTAVA et al., 2013; JANG et al., 2016). Assessing potential for contamination and exploitation conditions of water resources, better protection and conservation strategies can be established (NOBRE et al., 2007; ZUQUETTE; PALMA; PEJON, 2009; LASAGNA; CAVIGLIA; LUCA, 2014; COSTA et al., 2015c).

Several approaches have been developed for this purpose, and DRASTIC is the most widely used system (KABBOUR et al., 2006; RAHMAN, 2008; PACHECO; FERNANDES, 2013; PACHECO et al., 2015). However, the vulnerability of groundwater can vary over time, especially due to climate changes and land cover use. Previous studies in the state of São Paulo were developed collecting and classifying contamination-related activities connected to types of land uses (IRITANI et al., 2013), or relating these uses and natural environment conditions focusing in water resources vulnerability (ZUQUETTE et al., 2009).

Despite the advantages of preparing these maps, approaches that combine the classification of attributes for vulnerability mapping show some deficiencies concerning to attribution of weights and prioritization of attributes, resulting subjectivity to the process. Therefore, a more accessible and reliable mapping methodology should be developed to address the uncertainty of different scenarios in order to generate more reliable vulnerability maps at a regional scale (DIXON, 2005).
In order to reduce such subjectivity, this study used decision matrices as criteria to define the relative importance of the natural and manmade attributes that influence groundwater contamination potential. The process consists in combining the attributes of the natural and land use/land cover environmental conditions considering its prioritization based on an integrated analysis by a multidisciplinary team. The evaluation of the contamination potential was associated to data record of the contamination point sources, and the discussion of the relationship between these sources and the environmental conditions resulted in the classification of the contamination potential. This approach enabled to obtain the Groundwater Contamination Potential Map for Araras River Watershed and a set of recommendations for groundwater resources protection based on this potential and contamination sources in the urban area of the watershed.

\section{LOCATION AND CHARACTERIZATION OF THE STUDY AREA}

The Araras River Watershed (ARW) has an area of $352.77 \mathrm{~km}^{2}$ within the Water Resource Management Unit of the State of São Paulo (UGRH) of the Mogi Guaçu River - Upper Mogi and is located in the municipality of Araras (SP). The Araras River is a tributary of the Mogi Guaçu River and belongs to the basin of the Paraná River, which drains part of southern area of Brazil. The municipality of Araras has 118,843 inhabitants (IBGE, 2015) is located $155 \mathrm{~km}$ far from São Paulo, besides being a main economic center and fast growing population of South America. Its economy is mainly based on agriculture, characterized by intensive land use (Figure 1).

The study area presents eight aquifers units, divided in three groups (Figure 1): Sedimentary Aquifers (free aquifers, consisting of Alluvial, Pirambóia, Tatuí and Itararé formations, all having sandy matrix), Fractured Aquifers (semi-confined, composed by intrusive basic rocks from Serra Geral Formation) and Aquicludes (Corumbataí, Iratí and Itararé formations, clayed matrix).

Considering groundwater exploitation, according to Mineral Resources Research Company (CPRM), there are sixty-three wells in operation in the city, predominantly used for the industrial, commercial and agricultural sectors (CPRM, 2015).

Based on the works of Brollo (1991), Lollo (1991) and Aguiar (1995), the geological conditions of the basin were characterized. The Tubarão, Passa Dois and São Bento Groups are described briefly, with undifferentiated Quaternary coverage.

Tubarão Group consists of Itararé and Tatuí formations, having age between Upper Carboniferous and Medium Permian (359 to $245 \mathrm{Ma}$ ). The Itararé Formation (119.4 square kilometers in the area) consists of siltstone, claystone, mudstone, silty sandstone, fine to very fine sandstones. Tatuí Formation $\left(46.5 \mathrm{~km}^{2}\right.$ in the basin) consists of sandy siltstones, clayey siltstones, silty sandstones, mudstones and silty mudstones.

The Passa Dois Group was deposited in the Upper Permian $(\sim 299 \mathrm{Ma})$, and is composed by Irati $\left(16.2 \mathrm{~km}^{2}\right)$ and Corumbataí $\left(73.1 \mathrm{~km}^{2}\right)$ formations. The Iratí Formation consists of mudstones, siltstones, sandy siltstones, clayey siltstones and mudstones, with silicified limestone and dolomitic limestone in its upper portion. 
The Corumbataí Formation consists of mudstones, silty mudstones, clayey siltstones, sandy siltstones and fine to very fine sandstones.

The age of the São Bento Group is Mesozoic (245 to 65.5Ma) and consists of sedimentary deposits and intrusive and extrusive igneous basaltic rocks of the Paraná Basin. The Pirambóia Formation outcrops southwest of the basin $\left(16.7 \mathrm{~km}^{2}\right)$, where the source of the Furnas stream is located, and when it joins the Araras stream it forms the Araras River, in which sandstones are the predominant lithology. With a more distributed occurrence in the basin, the Serra Geral Formation $\left(74.6 \mathrm{~km}^{2}\right)$ has more significant areas in the southern and northern portions, predominantly consisting of tholeiitic basalts.

The basin also has the occurrence of Undifferentiated Cenozoic covers composed of continental sediments resulting from physical and/or chemical weathering of recent origin (Quaternary - 1.8Ma) which is distributed along valley bottoms in the northern and southwestern portions of the basin $\left(6.26 \mathrm{~km}^{2}\right)$, which are formed by silty sands, clayey sands, sandy clays, and clayey and sandy alluvium.

Soils units in the area presents differentiated thickness, texture, mineralogy, and permeability coefficient. The different units of these materials were defined and mapped by Brollo (1991), Lollo (1991) and Aguiar (1995) and Table 1 shows its main geotechnical properties.

In terms of relief on a continental scale, the region is inserted in the Tropical Morphoclimatic Domain of savannas and cerrados (AB'SABER, 2003). Regionally, ARW is located in the Paraná Sedimentary Basin Morphostructural Unit, Morphostructural Unit of the Paulista Peripheral Depression (Mogi-Guaçu Depression).

The relief forms, which constitute the dominant model, result from the denudation process, which forms hills with large tops and tabular tops. The degree of notching in the middle valleys

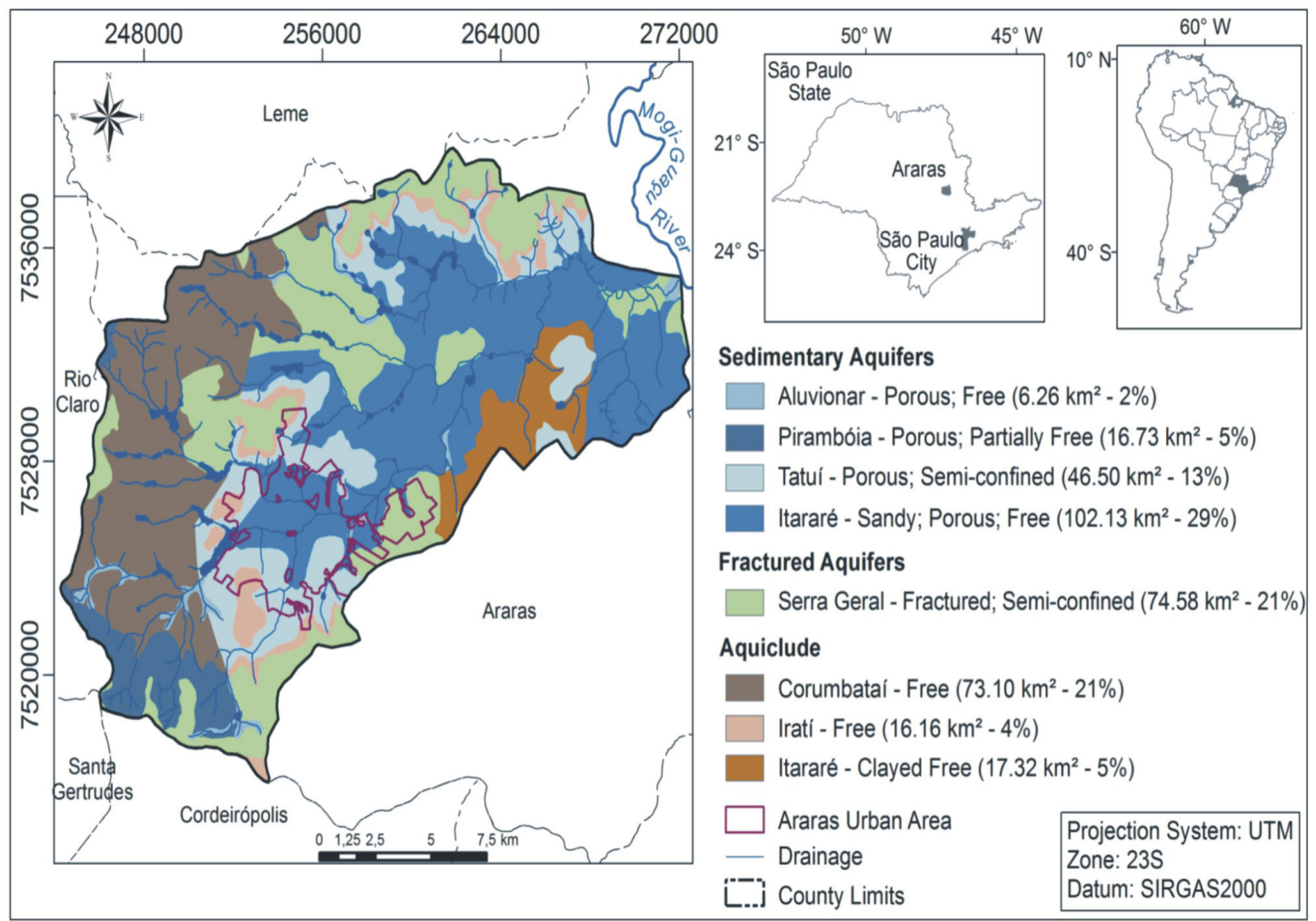

Figure 1. Location and aquifers map in the Araras Watershed.

Table 1. Geotechnical properties of soil types.

\begin{tabular}{|c|c|c|c|c|c|c|c|}
\hline \multirow{2}{*}{ Soils } & \multirow{2}{*}{ Area $\left(\mathrm{km}^{2}\right)$} & \multirow{2}{*}{$\begin{array}{l}\text { Soil Thickness } \\
\text { (m) }\end{array}$} & \multicolumn{4}{|c|}{ *-Granulometry $(\%)$} & \multirow{2}{*}{$\begin{array}{l}\text { Coefficient of permeability } \\
(\mathrm{cm} / \mathrm{s})\end{array}$} \\
\hline & & & $\mathrm{C}$ & $\mathrm{S}$ & FS & MS & \\
\hline Sandy Alluvial & 15.85 & $<2,>5$ & 22 & 17.5 & 57.5 & 3 & $1.19 \times 10^{-3}$ \\
\hline Clayey Alluvial & 10.84 & $<2,>5$ & 60 & 29 & 12.5 & 1.5 & $7.42 \times 10^{-6}$ \\
\hline Clayey Sand I & 76.11 & $<2,>5$ & 35 & 21 & 42 & 4.5 & $3.19 \times 10^{-2}$ \\
\hline Clayey Sand II & 50.07 & $<2,>5$ & 21 & 15.5 & 62.5 & 3 & $3.71 \times 10^{-3}$ \\
\hline Silty Sand & 6.57 & $<2,>5$ & 21.5 & 28.5 & 48 & 2 & $1.96 \times 10^{-3}$ \\
\hline Sandy Clay I & 125.62 & $<2,>5$ & 42.5 & 25.5 & 28 & 2.5 & $7.07 \times 10^{-5}$ \\
\hline Sandy Clay II & 27.16 & $<2,>5$ & 57 & 19 & 22.5 & 2.5 & $5.1 \times 10^{-7}$ \\
\hline Silty Clay I & 8.27 & $<2,>5$ & 41 & 36 & 20.5 & 1.5 & $1.34 \times 10^{-4}$ \\
\hline Silty Clay II & 12.44 & 2 to 5 and $>5$ & 54 & 31.5 & 15 & 1.5 & $5.5 \times 10^{-6}$ \\
\hline Silty Clay III & 19.84 & $<2,>5$ & 63.5 & 25.5 & 10.5 & 2 & $1.9 \times 10^{-6}$ \\
\hline
\end{tabular}

$* \mathrm{C}=$ Clay; $\mathrm{S}=$ Silt FS = Fine Sand MS = Medium sand. 
is "Very Low" $(<20 \mathrm{~m})$ and the average interfluvial size is "High" (from 1750 to $3750 \mathrm{~m}$ ). The altitude ranges from 584 to $785 \mathrm{~m}$, with predominant steepness of 10 to 20\% (ROSS; MOROZ, 1997).

According to the classification of Mendonça and Danni-Oliveira (2007), the type of climate of the region is the tropical climate of central Brazil without a dry period, with average annual rainfall of $1.450 \mathrm{~mm}$. Rains are frequent in the summer, particularly from December to March.

The forest formation of ARW is composed of two global hotspots: the Atlantic Forest and the Cerrado, with a predominance of the Atlantic formation of the semi deciduous forest (SÃO PAULO, 2009).

The hydrography has a dendritic drainage pattern (CHRISTOFOLETTI, 1974) and waterways of up to the 5th order (method by STRAHLER, 1952). The headwater sources of the Araras stream are located in the northwest (Corumbataí Formation), while the Furnas stream has sources in the southwest of the urban area of the municipality (Pirambóia Formation), where they meet to form the Araras River, and when crossing the Itararé Formation runs in the northeast direction, and changing to east in its final portion when it flows into the Mogi-Guaçu River.

\section{MATERIALS AND METHOD}

The addopted methodology consisted of main steps: 1) preparation of information plans in a GIS environment, 2) construction of aquifers units chart, 3) multi-criteria analysis based on decision matrix and attribution of weights, and 4) overlay of contamination sources on the potential of groundwater contamination chart (Figure 2).

In order to perform the algebra maps, the information plans were in matrix format, with the same cell size, in the same projection and reference system spatial (step 1). The information plans were georeferenced and projected in the SIRGAS2000

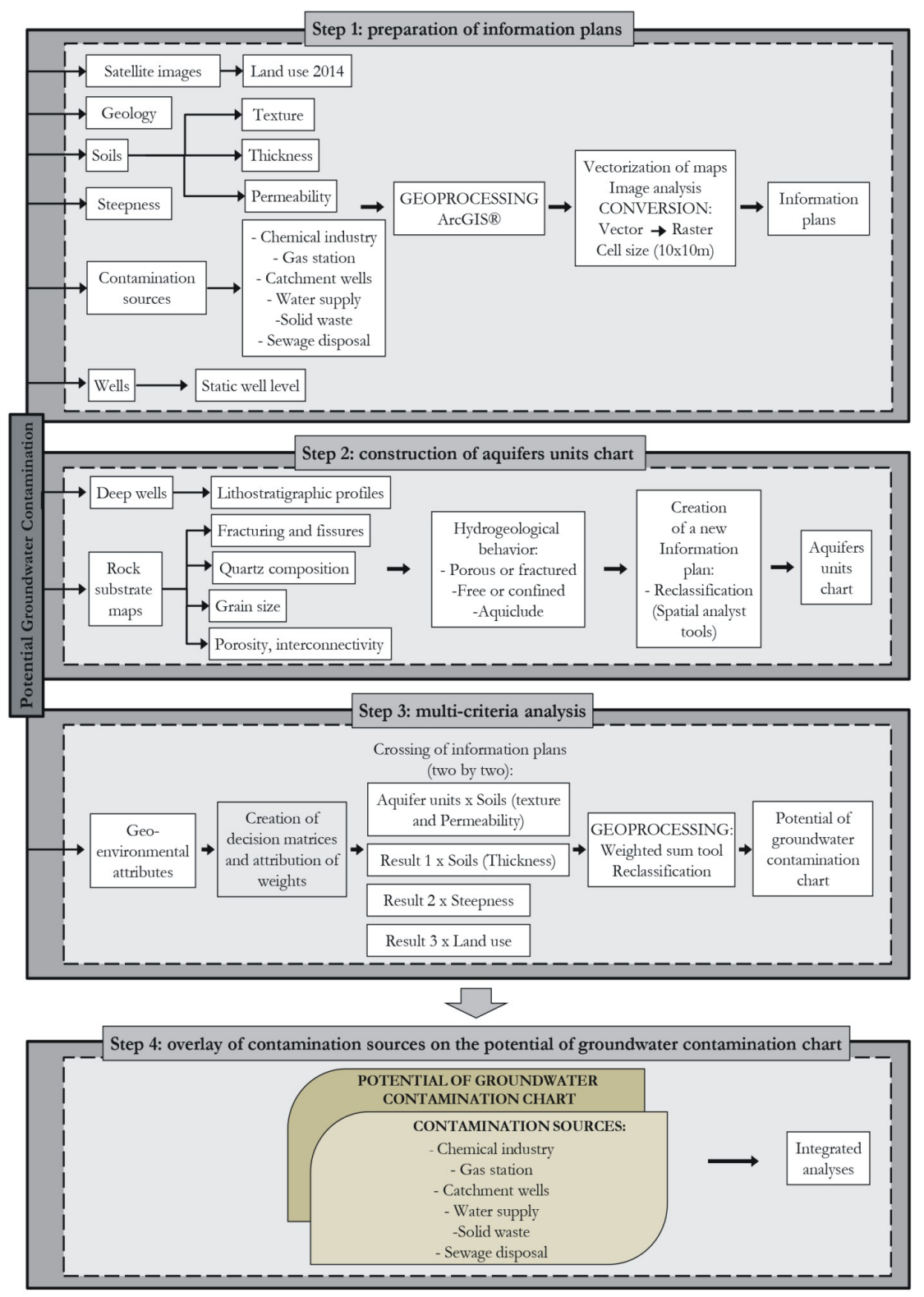

Figure 2. Flowchart of the method used. 
reference system (IBGE, 2005), Universal Transverse Mercator (UTM) projection, Zone 23S (Figure 3).

Aquifer units (step 2) are one of the primary attributes that have been considered to identify the potentials of groundwater contamination. This map (Figure 1) was produced from the of rock substrate maps, from lithostratigraphic profiles of deep wells. In GIS environmental, the geological maps were reclassified according to the hydrogeological and permeability behavior of rocks. The aquifer unit or aquiclude have been identified and reclassified in terms of capacity of water transmissivity and storage. The aquifers were classified as porous or fractured, free or confined and aquicludes.

The Multi-criteria Analysis (MCA) (step 3), requires using three types of data: criteria values (defined directly or indirectly by the relationship between the alternatives), weights (importance of one criterion in relation to another) and operation function (GIS with MCA integration) (MIRANDA, 2015). The latter is used to identify the potential contamination of the aquifers of ARW. The employed scale for potential for contamination was: very low, low, medium, high and very high.

The MCA was based on the methodology described by Costa et al. (2015a), which is the integration of information plans in a GIS environment by means of decision matrices using the Weighted Sum tool ArcGIS 10.2 software (ESRI, 2013). The cross-referencing of the geoenvironmental attributes were carried out two by two where values were attributed to the intersection of classes, and the weights, with values ranging from 1 to 5 (Very Low to Very High), were determined from the experience and expertise of the authors. The weights were decided in a group meeting.

Table 2 shows the geoenvironmental attributes used in this work and Tables 3 to 6 shows the crossing matrices.
A hierarchy was established to attribute weights to the aquifer units and the soil type. The sedimentary, porous, free and partially free aquifers (Aluvionar, Pirambóia, tatuí and Itararé Sandy), because of higher transmissivity and lower pollutant alleviation capacity, were given higher weights. On the other hand, fractured aquifers (Serra Geral), followed by aquiclude (Corumbataí, Iratí and Itararé clayed) received lower weights (Table 3).

The granulometric, hydraulic conductivity and thickness characteristics to soils define the percolation of water through the pores until it reaches the aquifer units. In this case, the sandy and less thick soils were given higher values to the detriment of soils with greater thickness and fine texture (Table 4).

Relief characteristics such the steepness, define the hydraulic gradient and the capacity of a pollutant to reach the aquifer. Therefore, in the steeper slopes was adopted a reduction of the weights applied to the groundwater contamination. In contrast, in plains areas ( 0 to $5 \%$ ) were adopted higher weights (Table 5).

Changes in regional groundwater vulnerability patterns are identified due to climatic variations, changes in land use and cover patterns or demands for water resources, which can be identified in time periods of years (DUCCI, 2005; LIMA; ROMANELLI; MASSONE, 2013; ALBUQUERQUE et al., 2013). For land use variations can occur over decades (AL-ADAMAT, FOSTER; BABAN, 2003; WORRALL; KOLPIN, 2004; VALLE JUNIOR et al., 2015), and can be evaluated by satellite image analysis from different time periods (SRIVASTAVA et al., 2013).

The presence of potentially contaminating activities, mainly industrial and commercial activities, and waste disposal, can also produce the potential for groundwater contamination (HOWARD, 2002; ZANTA et al., 2006).

Thus, potentially polluting activities, mainly industrial, commercial, agricultural and mining activities (HOWARD, 2002;

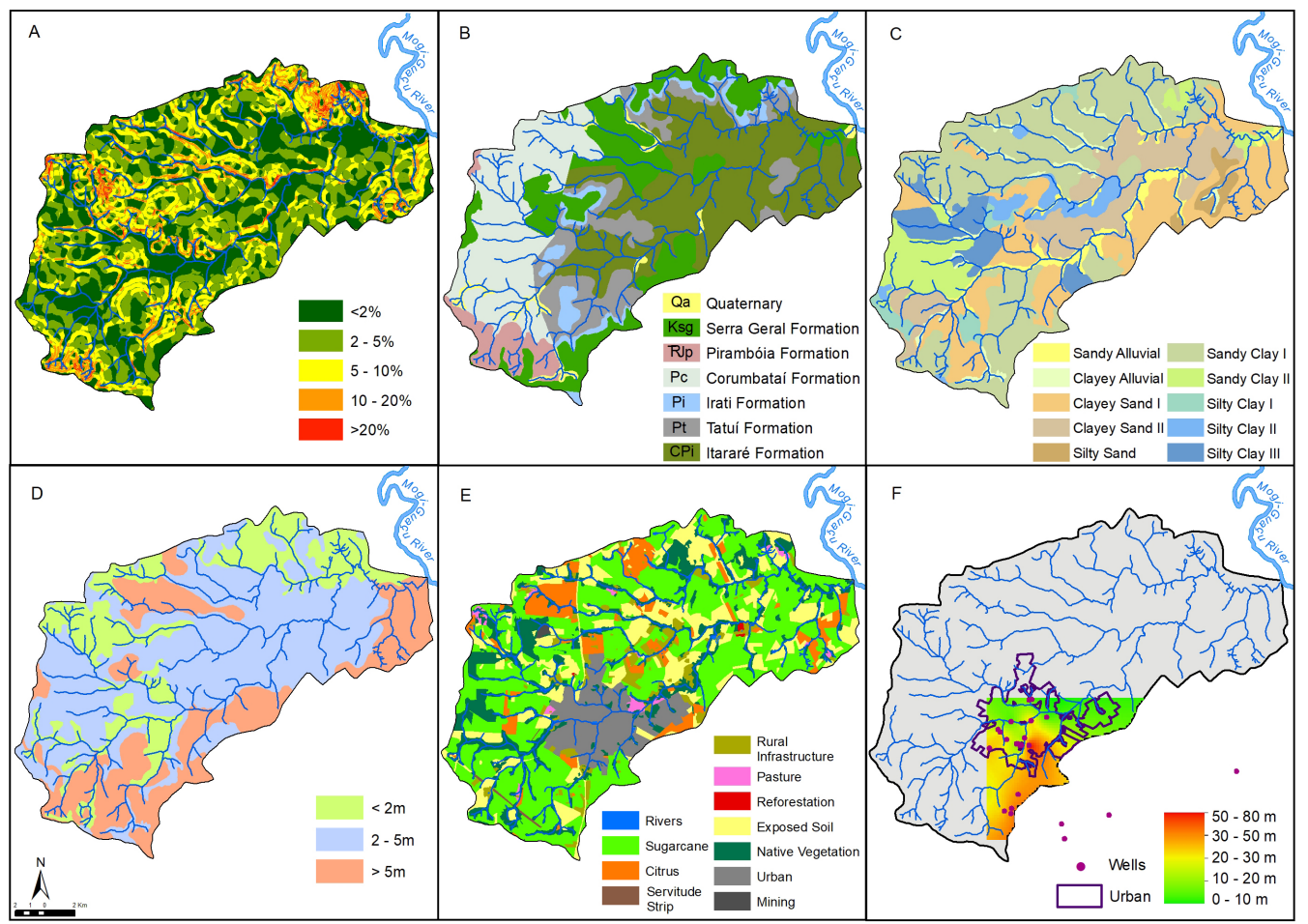

Figure 3. Environmental attributes in Araras river watershed: Steepness (A); Geology (B); Soils (C); Thickness soils (D); Land use and land cover - 2014 (E); Static Well Level (F). 
Table 2. Geo-environmental attributes/sources.

\begin{tabular}{ccc}
\hline Data & Description & Source \\
\hline Hydrography & Rivers & Topography charts (IBGE 1971a, 1971b, 1971c) \\
& & LANDSAT 8 image of 2014 \\
Relief & Steepness & Topography charts (IBGE 1971a, 1971b, 1971c) \\
& Araras - SF-23-Y-A-II-3 \\
& Conchal - SF-23- Y-A-II-4 \\
Leme - SF-23-Y-A-II-1 \\
Geological formations & Rock substrate maps & Araras Chart - Brollo (1991) \\
Soils & Cover materials & Leme Chart - Lollo (1991) \\
& & Conchal Chart - Aguiar (1995) \\
Land use and & LANDSAT 8, Path/Row \\
land cover - 2014 & 220/75 from 16/12/2014. \\
& Classes of land use & Colourful composition -: 6, 5 and 4 bands with panchromatic \\
Wells & fusion (15m Pixel) \\
& Location & CPRM (2015) \\
\hline
\end{tabular}

Table 3. Soil units $\times$ Aquifer units' decision matrix (First crossing).

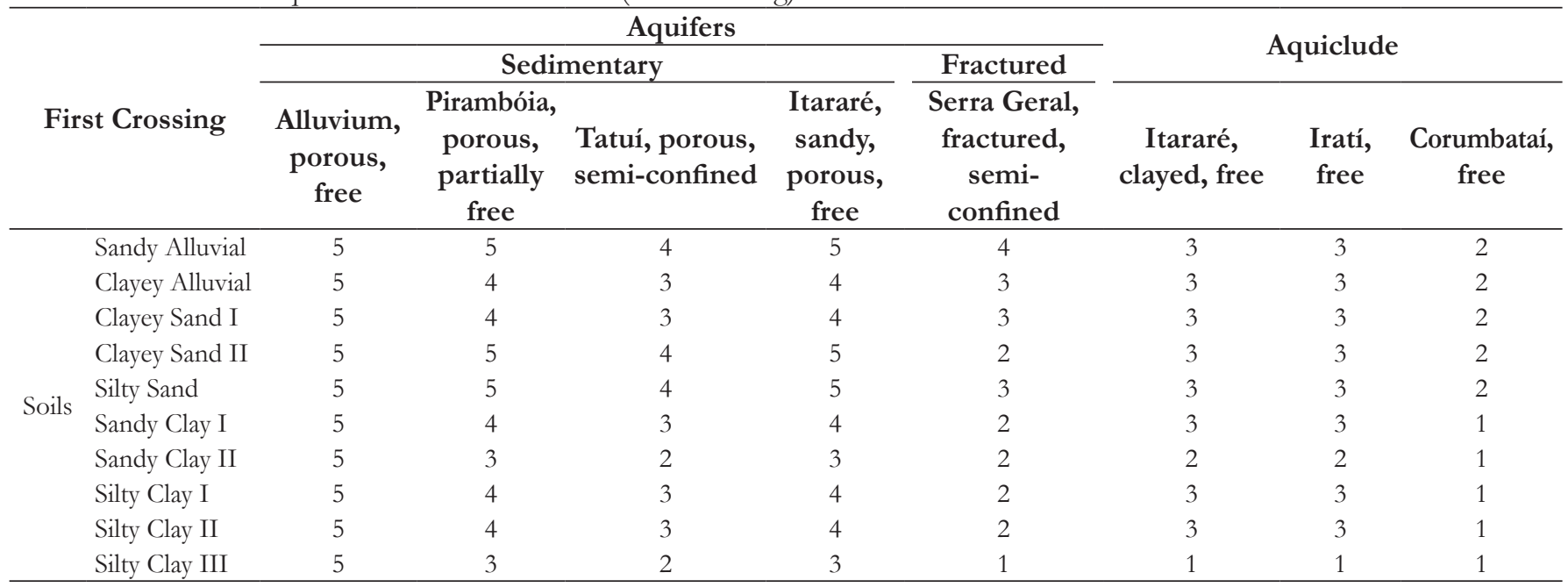

Table 4. First Crossing Results $\times$ Soil thickness decision matrix (Second Crossing).

\begin{tabular}{|c|c|c|c|c|}
\hline \multirow{2}{*}{\multicolumn{2}{|c|}{ Second Crossing }} & \multicolumn{3}{|c|}{ Soil Thickness (m) } \\
\hline & & Low $>5$ & $\begin{array}{l}\text { Medium } \\
2-5\end{array}$ & High $<2$ \\
\hline \multirow{5}{*}{ First result } & Very Low - 1 & 1 & 2 & 2 \\
\hline & Low -2 & 1 & 2 & 2 \\
\hline & Medium - 3 & 2 & 3 & 3 \\
\hline & High - 4 & 3 & 4 & 5 \\
\hline & Very High - 5 & 4 & 5 & 5 \\
\hline
\end{tabular}

Table 5. Second Crossing Results $\times$ Steepness decision matrix (Third Crossing).

\begin{tabular}{|c|c|c|c|c|c|c|}
\hline \multirow{2}{*}{\multicolumn{2}{|c|}{ Third Crossing }} & \multicolumn{5}{|c|}{ Steepness (\%) } \\
\hline & & \multirow{2}{*}{$\begin{array}{c}\mathbf{2} \mathbf{2 0} \\
1\end{array}$} & \multirow{2}{*}{$\frac{10-20}{1}$} & \multirow{2}{*}{$\frac{5-10}{1}$} & \multirow{2}{*}{$\frac{2-5}{2}$} & \multirow{2}{*}{$\frac{0-2}{2}$} \\
\hline Second & Very Low - 1 & & & & & \\
\hline \multirow{4}{*}{ result } & Low -2 & 1 & 1 & 2 & 3 & 3 \\
\hline & Medium - 3 & 2 & 2 & 3 & 4 & 4 \\
\hline & High - 4 & 3 & 4 & 4 & 5 & 5 \\
\hline & Very High - 5 & 3 & 4 & 5 & 5 & 5 \\
\hline
\end{tabular}

ZANTA et al., 2006) received the higher weights, on the other hand, activities such as grazing, reforestation and native vegetation received the lower weights (Table 6).

The database containing the contaminated areas in the State of São Paulo (CETESB, 2014) lists 16 areas registered in the Araras river watershed (ARW), and the location of the controlled landfill used until 2008 in the city is also a source of criticism (ALVES et al., 2014).

Considering the specific contamination sources, the operation and maintenance of tubular wells may result in contact between the contaminants and the water within the wellbore, or can facilitate it through the flow in the open spaces between the tubes and the ground (ANDERSON, 1987; HEATH, 2004; FOSTER et al., 2013), thereby enabling negative impacts on public health.

In the step 4, intending to consider possible groundwater contamination sources in addiction to natural environment data, and to complement the methodology proposed by Costa et al. (2015a); information related to sanitary sewage, water supply, solid waste and the location of contamination sources in Araras (IBGE, 2010) were included in this analysis (CETESB, 2014), 
as well as the layout and water level depth of the deep wells in operation in ARW (CPRM, 2015).

\section{RESULTS AND DISCUSSION}

Based on the proposed methodology, the attributes were cross-referenced to obtain the spatial representation of the potential contamination classes and the analysis of the potential effects of point sources related to the wells and the discharge of treatment systems.

Table 6. Third Crossing Results $\times$ Land use / land cover decision matrix (Fourth Crossing).

\begin{tabular}{|c|c|c|c|c|c|}
\hline \multirow[b]{2}{*}{$\begin{array}{l}\text { Fourth } \\
\text { Crossing }\end{array}$} & \multicolumn{5}{|c|}{ Third Result } \\
\hline & $\begin{array}{c}\text { Very Low } \\
-1\end{array}$ & $\begin{array}{c}\text { Low } \\
-2\end{array}$ & $\begin{array}{c}\text { Medium } \\
-3\end{array}$ & $\begin{array}{l}\text { High } \\
-4\end{array}$ & $\begin{array}{c}\text { Very } \\
\text { High } \\
-5\end{array}$ \\
\hline Sugar cane & 2 & 3 & 4 & 5 & 5 \\
\hline Rivers & 3 & 3 & 4 & 5 & 5 \\
\hline Citrus & 2 & 3 & 4 & 5 & 5 \\
\hline Servitude strip & 1 & 2 & 3 & 4 & 5 \\
\hline $\begin{array}{l}\text { Rural } \\
\text { infrastructure }\end{array}$ & 2 & 3 & 4 & 5 & 5 \\
\hline Pasture & 1 & 2 & 3 & 4 & 5 \\
\hline Reforestation & 2 & 3 & 3 & 4 & 5 \\
\hline Exposed soil & 2 & 3 & 4 & 5 & 5 \\
\hline $\begin{array}{l}\text { Native } \\
\text { Vegetation }\end{array}$ & 1 & 1 & 2 & 2 & 2 \\
\hline Urban & 2 & 3 & 4 & 5 & 5 \\
\hline Mining & 5 & 5 & 5 & 5 & 5 \\
\hline
\end{tabular}

Figure 4 shows the result obtained after fourth crossing in terms of groundwater contamination potential classes.

The very low potential class is distributed throughout the watershed, but occupies only a small part of the area $\left(22.02 \mathrm{~km}^{2}\right)$. The areas classified as very low potential show higher steepness, less permeable and thicker soils, and the presence of aquicludes, which resulted this classification.

Despite it, the main attribute that influenced classification was land use/land cover, in particular the presence of preserved native vegetation. The natural vegetation cover, in addition to not having a contaminant source, is a form of protection to the aquifer units. Therefore, it reduces the potential for contamination, independently of the other attributes.

The low potential class is also distributed throughout the basin, in a greater extent than the very low class $\left(66.69 \mathrm{~km}^{2}\right)$. Its occurrence relates mainly to the native vegetation and the steepness greater than $10 \%$. Higher steepness values favor surface runoff, reducing water infiltration and possible contamination; therefore, they were determinants in the reduction potential contamination in the locations where they are present.

The Alluvium Aquifer Unit, despite its natural characteristics that allow a high potential for contamination, is covered by natural vegetation, which reduced its contamination potential. The secondary determining condition for the low potential classification does not differ from those presented in the very low potential classification.

The average potential class is more significant in the western portion (west/northwest) and in the south/southeast portion of the basin $\left(75.57 \mathrm{~km}^{2}\right)$. Its environment shows steepness below $5 \%$, soil thicknesses greater than 2 meters, and aquifer units with

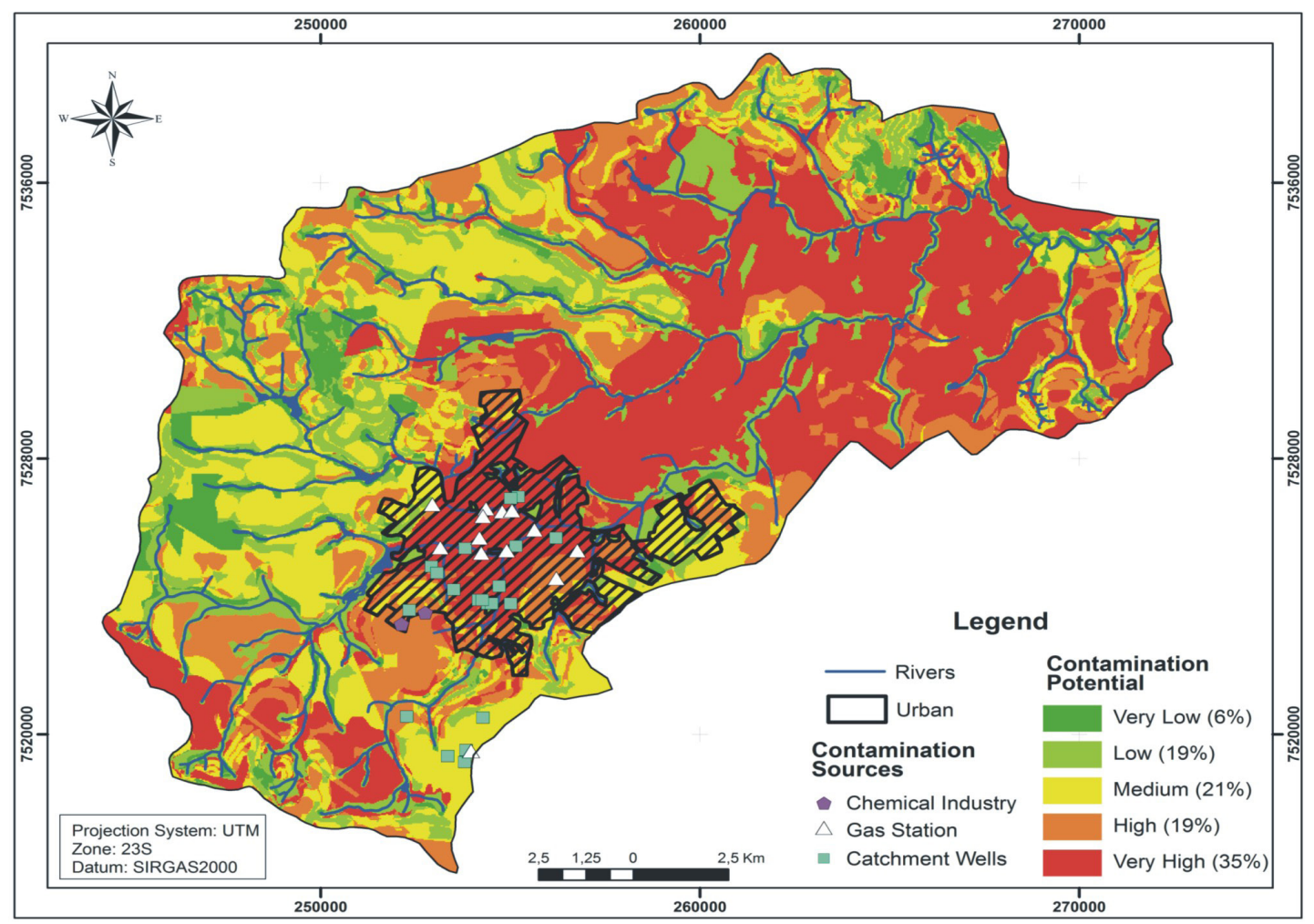

Figure 4. Map showing the potential for groundwater contamination caused by human activities. 
low average permeability and aquicludes, in which the presence of siltstones and mudstones limits fluid infiltration.

In the Serra Geral Aquifer Unit area, with a fractured and semi-confined characteristic, the presence of average and low permeability soils (between $10^{-5}$ and $10^{-6} \mathrm{~cm} / \mathrm{s}$ ), in the north-eastern portion of the basin, associated with the presence of medium and high steepness (above 10\%), conditioned this region to a medium potential contamination classification. Regarding the Corumbatai Aquifer Unit, despite its aquiclude condition, its medium potential classification occurred due to the soil thickness of less than 5 meters and the predominance of land use and land cover with sugarcane.

Although the occurrence of sugarcane cooperates with a lower soil infiltration capacity, due to the compaction caused by the use of agricultural machinery, as verified by Costa et al. (2015b), the contamination potential is also considered the most important attribute for this analysis. This fact is due to the large amounts of agrochemicals used during the cultivation process (PALMA et al., 2015).

The high potential class exhibits a widespread distribution throughout the basin, partially concentrated in the southwest. The high potential contamination attributes are attributed to low steepness, soils with average and high permeability and average to shallow thickness, with the presence of porous and semi-confined aquifers. However, the areas with the presence of Corumbataí aquiclude, combined with high permeability coefficients $\left(10^{-3} \mathrm{~cm} / \mathrm{s}\right)$, also showed a high contamination potential. The same occurs with the presence of the Irati aquicludes, associated with very low steepness (less than $2 \%$ ). In this case, the citriculture and sugarcane too make frequent use of agrochemicals and are sources of contamination of groundwater.
The very high potential class is the most abundant in the basin $\left(121.86 \mathrm{~km}^{2}\right)$. The attributes considered for the very high pollution potential classification were very low steepness, sandy soil profiles with very high permeability and very shallow thickness, porous and free aquifer units. The predominant characteristic in the configuration of this class was the type of groundwater unit, in which the occurrence of Sandy Itararé predominates. Regarding the land use and land cover, there is a predominance of exposed soil and sugarcane, in addition to urban areas. These activities occupy extensive areas and use agrochemicals frequently. In the urban area case, the urban sanitation system and the nitrate $\left(\mathrm{NO}_{3}\right)$ are the main contamination sources.

The Clayey Itararé aquifer unit is in the same potential class as the Sandy Itararé, because, despite having a clay matrix, it is covered by shallow soils (between 2 and $3 \mathrm{~m}$ ) and very high permeability $\left(10^{-3}\right.$ to $\left.10^{-2} \mathrm{~cm} / \mathrm{s}\right)$.

It should be noted that, although it is in the same classification, the planning and management guidelines for these two aquifer units should be differentiated. In the first, the measures enable greater control of agricultural techniques, while in the second one the potentially degrading activities of the soil should also be considered, in particular erosion.

Another groundwater unit that stood out was the Pirambóia aquifer (porous and partly free), which was decisive to the existence of an area with a very high class in the southwestern portion of the basin.

The potential sources of contamination were spatialized (Figure 5) regarding the means of water supply, solid waste and sewage disposal, per household, according to the census sectors in the city of Araras (IBGE, 2010).

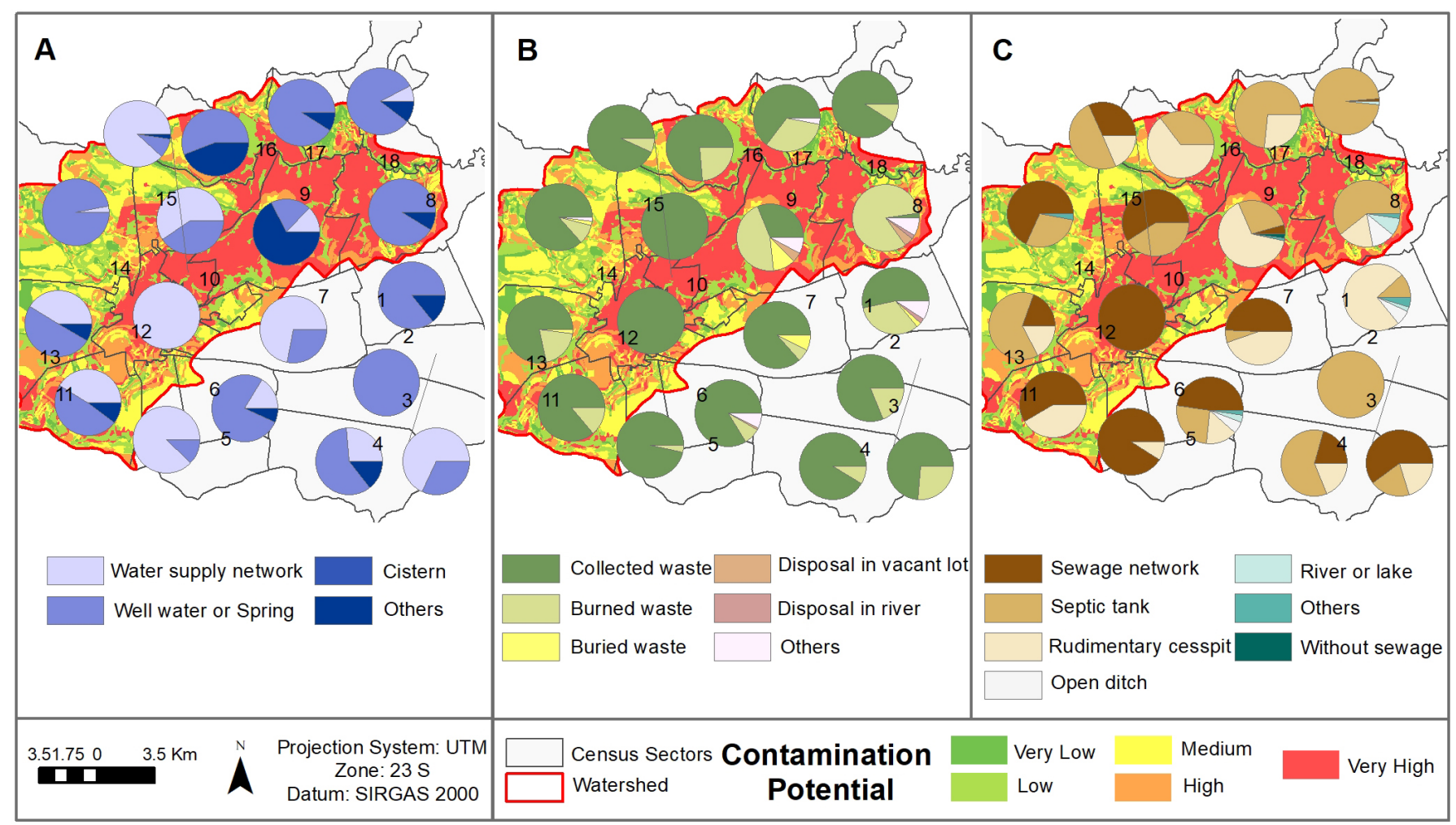

Figure 5. Potential contamination sources and census sectors: Water supply (A); Solid waste (B); Sanitary sewage (C). 
The water-supply data demonstrate the level of catchments per wells and sources in various sectors, especially the sectors 8 , 9 and 10, which are located in areas with very high potential for contamination. The presence of wells exposes the Sandy Itararé, Clayey Itararé and Tatuí aquifer units, which are more vulnerable to contaminants. A large portion of the urban area, located in sector 12, also displays the very high potential of contamination. Despite the predominant water supply network, the records show at least nineteen houses supplied by wells, resulting in similar or greater vulnerability conditions, which is due to the concentration of potentially contaminating activities, mainly industrial, commercial and waste disposal activities.

In ARW, solid waste disposal presents inadequate conditions, mainly in sectors 8 and 9, located in the regions with the highest potential for contamination. In these sectors, the buried and burned waste disposal and empty lots are emphasized. The precariousness of this disposal is greater in sector 9, where one hundred and six households improperly dispose their waste. Depending on the volume of improperly disposed waste there is the formation of leachate, which can reach the aquifer units.

Sewage is the component of basic sanitation that can cause major negative impacts on the quality of groundwater resources of ARW. The sectors 8, 9 and 16, which coincide with the regions of very high contamination potential, have the highest percentages of unsuitable conditions due to the use of rudimentary sewage pits, open trenches, disposal into water bodies or no proper sewage. The sectors 9 and 10 concentrate the highest number of houses that use rudimentary sewage tanks. In the urban areas of Araras watershed, despite extensive coverage of the sewage disposal system, there are still at least eleven houses that use rudimentary tanks and eleven without any form of sewage disposal, representing a groundwater contamination risk.

In addition to the contaminant sources related to sanitation, there are also those related to economic activities in urban areas. The Urban Division in Lots Law (BRASIL, 1979) determines relationships between contaminated areas and urban development, because it prohibits some forms of division in lots which are considered harmful, in addition to regulations that determine the owners are responsible for causing contamination.

The wells data of SIAGAS (CPRM, 2015) showed records that most of the wells produce water from the Tubarão Group aquifer in the Itararé Formation (predominant diamectites lithology, medium to coarse sandy matrix) and are located in the urban area, a part of the basin which also has the highest concentration of potential sources of contamination. There are thirty-nine exploitation wells in total (registered by SIAGAS) and sixteen confirmed contaminated areas in the city, of which fifteen are located in the watershed area. There are two chemical industries and thirteen gas stations. Most of these activities are located in areas classified as high and very high contamination potential in the urban area. In twelve contaminated areas, the impact on the groundwater has been confirmed and in the others the impacts on the surface soil. In nine areas, confirmatory studies informs free-flow hydrocarbon in underground, which indicates a condition that facilitates the substance reaching the catchment wells. As observed, most wells are close to the contaminated areas.
The static level data processing of the wells in the Itararé Formation in the watershed provided a spatial representation of depth classes, which show that most of the wells located in the urban areas and the areas with very high contamination potential exhibit static levels at depths lower than $30 \mathrm{~m}$, and some that have levels lower than $10 \mathrm{~m}$.

\section{CONCLUSIONS}

The potential contamination mapping of the aquifer units of ARW showed the predominance of very high and high potential classes (54\% of the area), mainly for the areas in the Itararé Formation (Sandy). The data related to the contaminant sources registered in the area indicate they are located in areas classified as "very high potential" class in the urban area of Araras.

The greatest potentials are largely related to the exploitation and recharging areas of the Itararé sedimentary aquifer, seriously increasing contamination potential. In these areas, inadequate techniques of wells construction and management, associated with highly urbanized areas, may result soil and groundwater contamination.

The correlation between areas classified as very high and high contamination potential related with areas that favor fluids infiltration, indicates that the method used was satisfactory. This was confirmed when the registered and investigated contaminated sites in the basin coincide with the areas that show a very high and high potential.

The results also show that the guidelines that should be implemented to protect groundwater should give special attention to the urban areas of the city of Araras, which has a high potential for contamination. This is the portion of the basin in which most of the wells are located, mainly in aquifer recharge areas. The drilling of wells in this area has to be controlled by strict management guidelines.

Considering Brazilian regulations, the most appropriate legal instruments are environmental licensing mechanisms, which are directed to the protection of groundwater resources, such as Environmental Impact Assessment, Neighborhood Impact Studies and specific recommendations in the Master Plan of the city.

These initiatives should also be implemented in sanitary sewage and waste disposal projects, and also special attention should be given to the projects of industrial districts.

\section{ACKNOWLEDGEMENTS}

Authors are grateful to CAPES for granting master's and doctoral scholarships to students of Postgraduate Programs Urban Engineering and Environmental Sciences, and to FAPESP for funding the Process 2013/03699-5.

\section{REFERENCES}

AB'SABER, A. N. Dominios de natureza no Brasil: potencialidades paisagísticas. São Paulo: Ateliê Editorial, 2003. 159 p.

AGUIAR, A. D. C. Mapeamento geotécnico da follha de Conchal, SP: Escala 1:50.000. 1995. 125 f. Dissertação (Mestrado em Geotecnia) - Escola de Engenharia de São Carlos, Universidade de São Paulo, 1995. 
AL HALLAQ, A. H.; ELAISH, B. S. A. Assessment of aquifer vulnerability to contamination in Khanyounis Governorate, Gaza Strip-Palestine, using the DRASTIC model within GIS environment. Arabian Journal of Geosciences, v. 5, n. 4, p. 833-847, 2012. http://dx.doi.org/10.1007/s12517-011-0284-9.

AL-ADAMAT, R. A. N.; FOSTER, I. D. L.; BABAN, S. M. J. Groundwater vulnerability and riskmapping for the Basaltic aquifer of the Azraq basin of Jordan using GIS, Remote sensing and DRASTIC. Applied Geography, v. 23, n. 4, p. 303-324, 2003. http://dx.doi.org/10.1016/j.apgeog.2003.08.007.

ALBUQUERQUE, M. T. D.; SANZ, G.; OLIVEIRA, S. F.; MARTÍNEZ-ALEGRÍA, R.; ANTUNES, I. M. H. R. Spatiotemporal groundwater vulnerability assessment - a coupled remote sensing and gis approach for historical land cover reconstruction. Water Resources Management, v. 27, n. 13, p. 4509-4526, 2013. http:/ / dx.doi.org/10.1007/s11269-013-0422-0.

ALVES, C. F. C.; BERTOLO, R. A.; ALVES, F. M.; OLIVEIRA, L. B. Geoquímica das águas subterrâneas de um aterro de resíduos sólidos urbanos em Araras, SP. Geologia USP Série Científica, v. 14, n. 2, p. 3-22, 2014. Available from: http://www.revistas.usp.br/ guspsc/article/view/85364. Access on: 21 nov. 2015.

AL-ZABET, T. Evaluation of aquifer vulnerability to contamination potential using the DRASTIC method. Environmental Geology, v. 43, n. 1, p. 203-208, 2002. http://dx.doi.org/10.1007/s00254002-0645-5.

ANDERSON, M. P. Hydrogeological framework for groundwater protection. In: PAGE, G. W. (Ed.). Planning for groundwater protection. London: Academic Press, 1987. p. 9-12.

BETANCUR, T.; PALACIO, C.; GAVIRIA, J. I.; RUEDA, M. Methodological proposal to assess groundwater contamination danger: study case of Bajo Cauca aquifer (Colombia). Environmental Earth Sciences, v. 70, n. 1, p. 315-328, 2013. http://dx.doi.org/10.1007/ s12665-012-2129-6.

BRASIL. Lei $n^{\circ}$ 6.766. Dispõe sobre o parcelamento do solo urbano e dá outras providências. Diário Oficial [da] República Federativa do Brasil, Brasília, DF, 19 dez. 1979. Available from: http://www. planalto.gov.br/ccivil_03/leis/16766.htm. Access on: 21 nov. 2015.

BROLLO, M.J. Mapeamento geotécnico da quadrícula de Araras, SP Escala 1:50.000. 1991. 88 f. Dissertação (Mestrado em Geotecnia) - Escola de Engenharia de São Carlos, Universidade de São Paulo, 1991.

CETESB - Companhia Ambiental do Estado de São Paulo. Áreas contaminadas do Estado de São Paulo. São Paulo: CETESB, 2014. Available from: http://areascontaminadas.cetesb.sp.gov. br/relacao-de-areas-contaminadas/. Access on: 21 nov. 2015.

CHRISTOFOLETTTI, A. Geomorfologia. 1. ed. São Paulo: EDUSP, 1974. $149 \mathrm{p}$.
COSTA, C. W.; MORAES, M. C. P.; CANÇADO, C. J.; GUERRERO, J. V. R.; MARANGON, F.; LORANDI, R.; LOLLO, J. A.; MOSCHINI, L. E. Potencial de contaminação de aquíferos por atividades antrópicas da Bacia do Ribeirão do Meio - Município de Leme - SP. Revista Brasileira de Recursos Hídricos, v. 20, n. 1, p. 218-225, 2015a. http://dx.doi.org/10.21168/rbrh.v20n1.p218-225.

COSTA, C. W.; PIGA, F. G.; MORAES, M. C. P.; DORICI, M.; SANGUINETTO, E. C.; LOLLO, J. A.; MOSCHINI, L. E.; LORANDI, R.; OLIVEIRA, L. J. Fragilidade ambiental e escassez hídrica em bacias hidrográficas: Manancial do Rio das Araras Araras, SP. Revista Brasileira de Recursos Hidricos, v. 20, n. 4, p. $946-$ 958, 2015b. http://dx.doi.org/10.21168/rbrh.v20n4.p946-958.

COSTA, L.; MONTEIRO, J. P.; OLIVEIRA, M.; MOTA, R.; LOBO-FERREIRA, J. P.; MARTINS DE CARVALHO, J.; CARVALHO, T. M.; AGOSTINHO, R.; HUGMAN, R. Modelling Contributions of the Local and Regional Groundwater Flow of Managed Aquifer Recharge Activities at Querença-Silves Aquifer System. In: EGU General Assembly 2015, 17., 12-17 April 2015, Wien. Geophysical Research Abstracts, Wien: EGU, 2015c. p. 11930.

CPRM - Serviço Geológico do Brasil. SLAGAS: Sistema de Informações de Águas Subterrâneas. 2015. Available from: http:/ / siagasweb.cprm.gov.br/layout/pesquisa_complexa.php2015. Access on: 21 nov. 2015.

DIXON, B. Groundwater vulnerability mapping: a GIS and fuzzy rule based integrated tool. Applied Geography, v. 25, n. 4, p. 327-347, 2005. http://dx.doi.org/10.1016/j.apgeog.2005.07.002.

DUCCI, D. Influence of climate changes on vulnerability maps. In: First Conference and Workshop on "Groundwater and Climate Change”, 1., Norwich. Norwich: University of East Anglia, 2005. p. 1-6.

DUCCI, D.; SELLERINO, M. Vulnerability mapping of groundwater contamination based on 3D lithostratigraphical models of porous aquifers. The Science of the Total Environment, v. 447, p. 315-322, 2013. PMid:23391897. http://dx.doi.org/10.1016/j.scitotenv.2012.12.090.

EDET, A. An aquifer vulnerability assessment of the Benin Formation aquifer, Calabar, southeastern Nigeria, using DRASTIC and GIS approach. Environmental Earth Sciences, v. 71, n. 4, p. 1747-1765, 2014. http://dx.doi.org/10.1007/s12665-013-2581-y.

ESRI - Environmental Systems Research Institute. ArcGIS for the desktop 10.2.2. Redlands, CA: ESRI, 2013.

FOSTER, S.; HIRATA, R.; ANDREO, B. The aquifer pollution vulnerability concept: aid or impediment in promoting groundwater protection? Hydrogeology Journal, v. 21, n. 7, p. 1389-1392, 2013. http://dx.doi.org/10.1007/s10040-013-1019-7.

FUEST, S.; BERLEKAMP, J.; KLEIN, M.; MATTHIES, M. Risk hazard mapping of groundwater contamination using longterm monitoring data of shallow drinking water wells. Journal of 
Hazardous Materials, v. 61, n. 1, p. 197-202, 1998. http://dx.doi. org/10.1016/S0304-3894(98)00123-X.

GREEN, T. R.; TANIGUCHI, M.; KOOI, H.; GURDAK, J. J.; ALLEN, D. M.; HISCOCK, K. M.; TREIDEL, H.; AURELI, A. Beneath the surface of global change: impacts of climate change on groundwater. Journal of Hydrology, v. 405, n. 3, p. 532-560, 2011. http://dx.doi.org/10.1016/j.jhydrol.2011.05.002.

HEATH, R. C. Supply-well problems: changes in water quality. In: HEATH, R.C. Basic ground-water bydrology. 10th ed. Denver: U.S. Geological Survey, p. 78-79, 2004.

HOWARD, K. W. F. Urban groundwater issues - an introduction. In: HOWARD, K. W. F; ISRAFILOV, R. G. (Eds.). Currentproblems of bydrology in urban areas, urban agglomerates and industrial centres. Netherlands: Springer, 2002. p. 1-16.

IBGE - INSTITUTO BRASILEIRO DE GEOGRAFIA E ESTATÍSTICA. Folba Topográfica: Leme (SF-23-Y-A-II-1). Rio de Janeiro, 1971a. Escala 1:50.000.

IBGE - INSTITUTO BRASILEIRO DE GEOGRAFIA E ESTATÍSTICA. Folba Topográfica: Araras (SF-23-Y-A-II-3). Rio de Janeiro, 1971b. Escala 1:50.000.

IBGE - INSTITUTO BRASILEIRO DE GEOGRAFIA E ESTATÍSTICA. Folha Topográfica: Conchal (SF-23- Y-A-II-4). Rio de Janeiro, 1971c. Escala 1:50.000.

IBGE - INSTITUTO BRASILEIRO DE GEOGRAFIA E ESTATISTICA. Resolução No 1/2005. Estabelece o Sistema de Referência Geocêntrico para as Américas (SIRGAS). Diário Oficial [da] República Federativa do Brasil, Brasília, DF, 7 jan. 2005. Available from: ftp://geoftp.ibge.gov.br/documentos/geodesia/projeto_ mudanca_referencial_geodesico/legislacao/rpr_01_25fev2005. pdf. Access on: 21 nov. 2015.

IBGE - INSTITUTO BRASILEIRO DE GEOGRAFIA E ESTATISTICA. Censo 2010. Rio de Janeiro: IBGE, 2010. Available from: http://www.ibge.gov.br/cidadesat/link.php?codmun=351950. Access on: 21 nov. 2015.

IBGE - INSTITUTO BRASILEIRO DE GEOGRAFIA E ESTATISTICA. IBGE Cidades. Rio de Janeiro: IBGE, 2015. Available from: http://www.cidades.ibge.gov.br/xtras/perfil. php?lang $=\&$ codmun $=350330 \&$ search $=$ sao-paulo $\mid$ araras. Access on: 21 nov. 2015.

IRITANI, M. A.; EZAKI, S. Cadernos de educação ambiental 1: as águas subterrâneas do Estado de São Paulo. 2. ed. São Paulo: Secretaria de Estado do Meio Ambiente, 2009. Available from: http://www. igeologico.sp.gov.br. Access on: 21 nov. 2015.

IRITANI, M. A.; ROSSINI-PENTEADO, D.; EZAKI, S.; ODA, G. H. Proposta de classificação das fontes potenciais de contaminação da água subterrânea. Revista do Instituto Geológico, v. 34, n. 2, p. 1-26, 2013. Available from: http://ppegeo.igc.usp.br/
scielo.php?pid=S0100-929X2013000200001\&script=sci_arttext. Access on: 21 nov. 2015.

JACKSON, R. E.; DWARAKANATH, V. Chlorinated decreasing solvents: physical $\square$ chemical properties affecting aquifer contamination and remediation. Ground Water Monitoring and Remediation, v. 19, n. 4, p. 102-110, 1999. http://dx.doi.org/10.1111/j.1745-6592.1999. tb00246.x.

JANG, C.; LIN, C.; LIANC, C.; CHEN, J. Developing a reliable model for aquifer vulnerability. Stochastic Environmental Research and Risk Assessment, v. 30, n. 1, p. 175-187, 2016. http://dx.doi. org/10.1007/s00477-015-1063-z.

KABBOUR, B. B.; ZOUHRI, L.; MANIA, L.; COLBEAUX, J. P. Assessing groundwater contamination risk using the DASTI/ IDRISI GIS method: coastal system of western Mamora, Morocco. Bulletin of Engineering Geology and the Environment, v. 65, n. 4, p. 463-470, 2006. http:/ /dx.doi.org/10.1007/s10064-004-0265-2.

LASAGNA, M.; CAVIGLIA, C.; LUCA, D. A. Simulation modelling for groundwater safety in an overexploitation situation: the Maggiore Valley context (Piedmont, Italy). Bulletin of Engineering Geology and the Environment, v. 73, n. 2, p. 341-355, 2014. http:// dx.doi.org/10.1007/s10064-013-0500-9.

LI, R.; MERCHANT, J. W. Modeling vulnerability of groundwater to pollution under future scenarios of climate change and biofuelsrelated land use change: a case study in North Dakota, USA. The Science of the Total Environment, v. 447, p. 32-45, 2013. PMid:23376514. http://dx.doi.org/10.1016/j.scitotenv.2013.01.011.

LIMA, M. L.; ROMANELLI, A.; MASSONE, H. E. Decision support model for assessing aquifer pollution hazard and prioritizing groundwater resources management in the wet Pampa plain, Argentina. Environmental Monitoring and Assessment, v. 185, n. 6, p. 5125-5139, 2013. PMid:23054292. http://dx.doi.org/10.1007/ s10661-012-2930-4.

LOLLO, J. A. Mapeamento geotécnico da folha de Leme, SP: utilização da geomorfologia para a caracterização preliminar de Unidades Geotécnicas. 1991. 87 f. Dissertacao (Mestrado em Geotecnia) Escola de Engenharia de São Carlos, Universidade de São Paulo, 1991.

MENDONÇA, F;; DANNI-OLIVEIRA, I. M. Climatologia: noções básicas e climas do Brasil. São Paulo: Oficina de Textos, 2007.

MENEZES, J. P. C. D.; BERTOSSI, A. P. A.; SANTOS, A. R.; NEVES, M. A. Correlação entre uso da terra e qualidade da água subterrânea. Engenharia Sanitaria e Ambiental, v. 19, n. 2, p. 173-186, 2014. http://dx.doi.org/10.1590/S1413-41522014000200008.

MENG, X.; DENG, B.; SHAO, J.; YIN, M.; LIU, D.; HU, Q. Confined aquifer vulnerability induced by a pumping well in a leakage area. Proceedings of the International Association of Hydrological Sciences, v. 368, p. 442-447, 2015. http://dx.doi.org/10.5194/ piahs-368-442-2015. 
MIRANDA, J. I. Avanços na análise espacial - análise multicritério. In: MIRANDA, J. I. Sistemas de informações geográficas. 4. ed. Brasília: Embrapa, 2015. p. 289.

NOBRE, R. C.; ROTUNNO FILHO, O. C.; MANSUR, W. J.; NOBRE, M. M.; COSENZA, C. A. Groundwater vulnerability and risk mapping using GIS, modeling and a fuzzy logic tool. Journal of Contaminant Hydrology, v. 94, n. 3, p. 277-292, 2007. PMid:17728007. http://dx.doi.org/10.1016/j.jconhyd.2007.07.008.

ODLING, N. E.; SERRANO, R. P.; HUSSEIN, M. E. A.; RIVA, M.; GUADAGNINI, A. Detecting the vulnerability of groundwater in semi-confined aquifers using barometric response functions. Journal of Hydrology, v. 520, p. 143-156, 2015. http://dx.doi. org/10.1016/j.jhydrol.2014.11.016.

PACHECO, F. A. L.; PIRES, L. M. G. R.; SANTOS, R. M. B.; FERNANDES, L. F. S. Factor weighting in DRASTIC modeling. The Science of the Total Environment, v. 505, p. 474-486, 2015. PMid:25461049. http://dx.doi.org/10.1016/j.scitotenv.2014.09.092.

PACHECO, F. A. L.; FERNANDES, L. F. The multivariate statistical structure of DRASTIC model. Journal of Hydrology, v. 476, p. 442-459, 2013. http://dx.doi.org/10.1016/j.jhydrol.2012.11.020.

PALMA, J. B.; SCUDELARIABILIO, G.; MATOS, S. L. F. Contaminação de materiais geológicos e da água subterrânea. In: ZUQUETTE, L. V. Geotecnia ambiental. Rio de Janeiro: Elsevier, 2015. p. $183-213$.

RAHMAN, A. A GIS based DRASTIC model for assessing groundwater vulnerability in shallow aquifer in Aligarh, India. Applied Geography, v. 28, n. 1, p. 32-53, 2008. http://dx.doi. org/10.1016/j.apgeog.2007.07.008.

ROSS, J. L. S.; MOROZ, I. C. Mapa geomorfológico do Estado de São Paulo. São Paulo: FFLCH-USP/IPT/FAPESP, 1997.

SÃO PAULO. Inventário florestal da vegetação natural do Estado de São Paulo. São Paulo: Instituto Florestal do Estado de São Paulo, 2009. Available from: http://www.iflorestal.sp.gov.br/sifesp/inventario. html. Access on: 21 nov. 2015.

SRIVASTAVA, P. K.; SINGH, S. K.; GUPTA, M.; THAKUR, J. K.; MUKHERJEE, S. Modeling impact of land use change trajectories on groundwater quality using remote sensing and GIS. Environmental Engineering and Management Journal, v. 12, n. 12, p. 2343-2355, 2013.

STRAHLER, A. N. Hypsometric (area-altitude) analysis of erosional topography. Geological Society of America Bulletin, v. 63, n. 11, p. 1117-1142, 1952. http://dx.doi.org/10.1130/00167606(1952)63[1117:HAAOET]2.0.CO;2.

VALLE JUNIOR, R. F.; VARANDAS, S. G. P.; FERNANDES, L. F. S.; PACHECO, F. A. L. Multi criteria analysis for the monitoring of aquifer vulnerability: a scientific tool in environmental policy.
Environmental Science \& Policy, v. 48, p. 250-264, 2015. http://dx.doi. org/10.1016/j.envsci.2015.01.010.

WORRALL, F.; KOLPIN, D. W. Aquifer vulnerability to pesticide pollution-combining soil, land-use and aquifer properties with molecular descriptors. Journal of Hydrology, v. 293, n. 1, p. 191-204, 2004. http://dx.doi.org/10.1016/j.jhydrol.2004.01.013.

WWAP. The United Nations World Water Development Report 2015: water for a sustainable world. Paris: United Nations World Water Assessment Programme, UNESCO, 2015. Available from: http:/ / unesdoc.unesco.org/images/0023/002318/231823E.pdf. Access on: 21 nov. 2015.

ZANTA, V. M.; MARINHO, M. J. M. R.; LANGE, L. C.; PESSIN, N. Resíduos sólidos, saúde e meio ambiente: impactos associados aos lixiviados de aterro sanitário. In: CASTILHOS JÚNIOR, A. B. Gerenciamento de resíduos sólidos urbanos com ênfase na proteção de corpos d'água: prevenção, geração e tratamento de lixiviados de aterros. Rio de Janeiro: ABES, 2006. p. 1-16.

ZUQUETTE, L. V.; PALMA, J. B.; PEJON, O. J. Methodology to assess groundwater pollution conditions (current and predisposition) in the São Carlos and Ribeirão Preto regions, Brazil. Bulletin of Engineering Geology and the Environment, v. 68, n. 1, p. 117-136, 2009. http:/ /dx.doi.org/10.1007/s10064-008-0173-y.

\section{Authors contributions}

Fabiola Geovanna Piga: Contributed to the methodology adopted, discussion of the results and conclusion, bibliographical research. Elaborated introduction, methodology, discussion of results, conclusion, writing and preparation of figures and tables. Organization and compliance with the journal guidelines, and paper final revision.

Nicolas Guerra Rodrigues Tao: Contribution in the paper conception, implementation of the methodology, bibliographical research, tabulation of adopted crosses, survey of pollution sources, as well as discussion of results and conclusion. Participated in the elaboration of the introduction, discussion of results, conclusion and figures.

Mayara Herrmann Ruggiero: Contributed to the methodology adopted, tabulation of crosses used, survey of pollution sources, as well as discussion of results and conclusion. Collaborated in the elaboration of the introduction, bibliographical research, discussion of results, conclusion and figures.

Darlan de Souza Marquezola: Contributed to the execution of the adopted methodology, as well as in the discussion of the results and conclusion. Acted in bibliographical research, and writing the methodology and conclusion. 
Welliton Leandro de Oliveira Beret: Contributed to the elaboration of the methodology, digitization of the database (static wells level), discussion of results and figures.

Carlos Wilmer Costa: responsible for the Organization of the database, contributed to the orientation of the Methodology adopted in the work, elaboration of the methodology, characterization of the study area, discussion of results and conclusion, and paper final revision.

José Augusto de Lollo: Contributed to the digitization of the hydrogeological database, in the elaboration of the summary and the methodology, discussion of the results, conclusion and paper final revision.
Reinaldo Lorandi: Senior Researcher. Responsible for choosing the study area and survey of the geographical data used in bibliographic sources. Participated in the elaboration of the methodology, discussion of the results and elaboration of the summary.

Edson Augusto Melanda: Contributed to the orientation of the paper, in the elaboration of the introduction and discussion of the results.

Luis Eduardo Moschini: Contributed to the guidance on the use of the ArcGis 10.2.2 application used in the digitization of the database and in the weighted sum of the geoenvironmental attributes, in the choice of the periodical, elaboration of the methodology and discussion of the Results. 